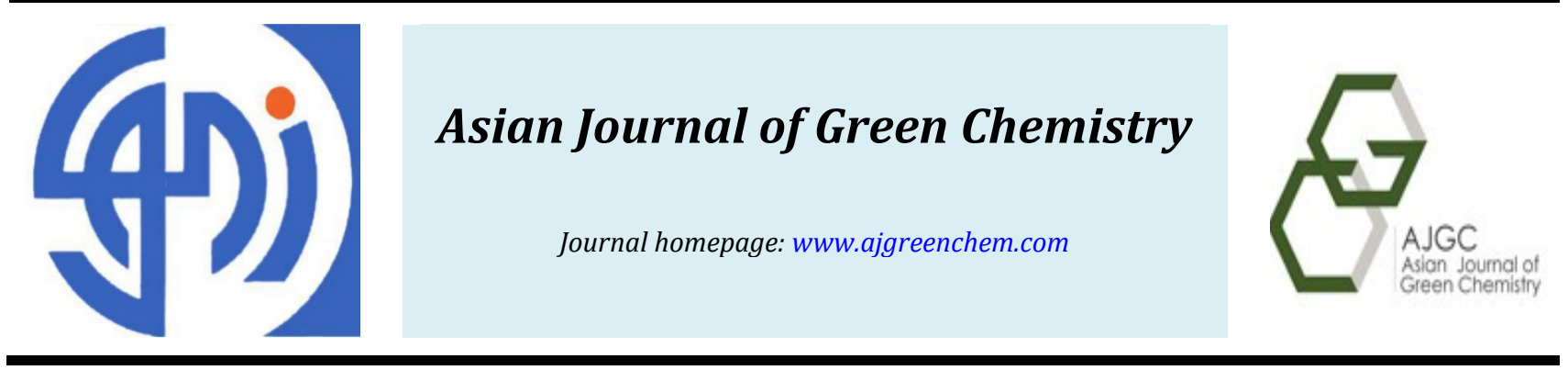

Original Research Article

\title{
Identification of lectins from the seeds of Bangladeshi plants Sesbania bispinosa and Senna occidentalis by hemagglutination assay
}

\author{
Mst. Jesmin Sultanaa,*, Fazle Rabbi Shakil Ahmed ${ }^{b}$, M. Taufiq Alam ${ }^{c}$ \\ a Department of Materials Science and Engineering, Faculty of Engineering, University of Rajshahi, Rajshahi, Bangladesh \\ b Department of Pharmacy, Khwaja Yunus Ali University, Sirajgonj, Bangladesh \\ c Department of Applied Chemistry and Chemical Engineering, Faculty of Engineering,University of Rajshahi, Rajshahi, \\ Bangladesh
}

\begin{tabular}{|c|c|}
\hline ARTICLE INFORMATION & ABSTRACT \\
\hline $\begin{array}{l}\text { Received: } 2 \text { October } 2018 \\
\text { Received in revised: } 1 \text { November } 2018 \\
\text { Accepted: } 11 \text { November } 2018 \\
\text { Available online: } 2 \text { February } 2019 \\
\text { DOI: } 10.33945 / \text { SAMI/AJGC/2019.4.8 } \\
\text { KEYWORDS } \\
\text { Hemagglutination } \\
\text { lectin } \\
\text { blood group } \\
\text { Sesbania bispinosa } \\
\text { Senna occidentalis }\end{array}$ & $\begin{array}{l}\text { Hemagglutination assay is a simple and easy method to specify a lectin. An } \\
\text { active lectin agglutinates erythrocytes by recognizing a carbohydrate on the } \\
\text { cell surface and forming a cross-linked network in suspension. The assay is } \\
\text { traditionally performed on a microtiter plate, where the lectin solution is } \\
\text { serially diluted and the minimum concentration of a lectin causing } \\
\text { agglutination is detected. The crude extract of Senna occidentalis and } \\
\text { Sesbania bispinosa seeds contain considerable amount of protein. It was } \\
\text { found that } 10 \mathrm{gm} \text { of Sesbania bispinosa and Senna occidentalis seeds contain } \\
\text { about } 12.6 \mathrm{mg} / \mathrm{mL} \text { and } 9.8 \mathrm{mg} / \mathrm{mL} \text { of protein, and minimum agglutination } \\
\text { concentration was found to be } 0.393 \mathrm{mg} / \mathrm{mL} \text { for Sesbania bispinosa in each } \\
\text { group of human erythrocytes }(\mathrm{A}, \mathrm{B}, \mathrm{O} \text { and } \mathrm{AB}) \text { and } 0.613 \mathrm{mg} / \mathrm{mL} \text { for Senna } \\
\text { occidentalis in chicken erythrocytes. Finally, the hemagglutination assay } \\
\text { confirmed that possible lectins present in the Sesbania bispinosa and Senna } \\
\text { occidentalis plant sources. }\end{array}$ \\
\hline
\end{tabular}




\section{Graphical Abstract}

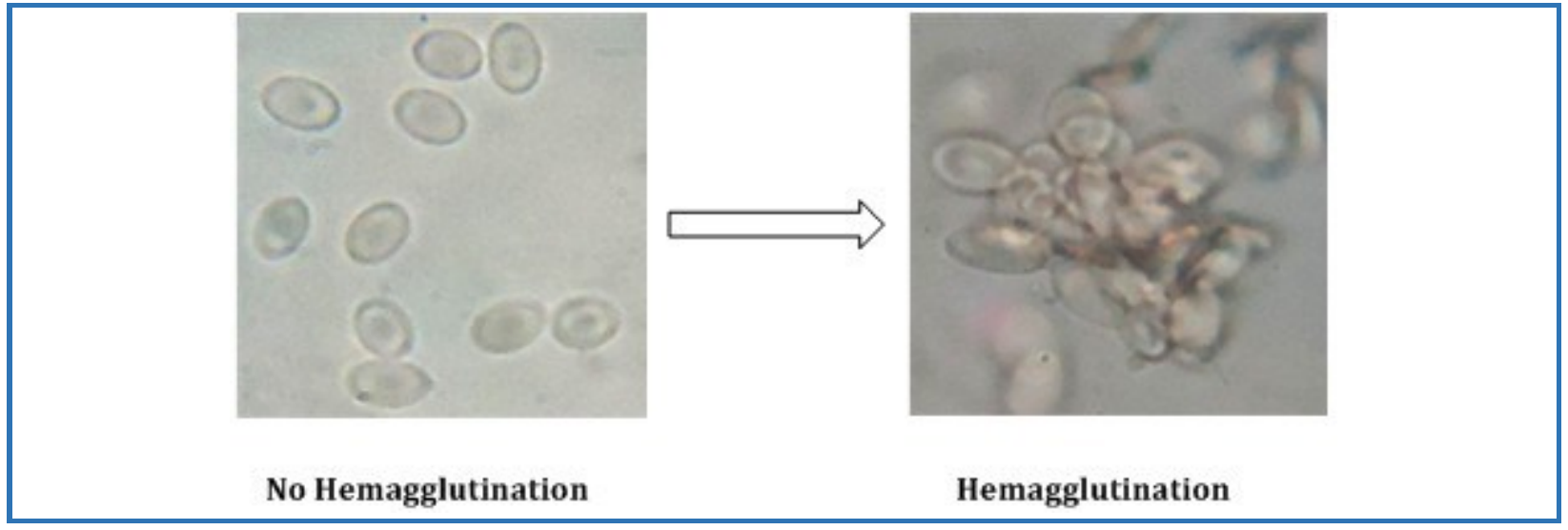

\section{Introduction}

Lectins can be defined as a group of proteins found in all types of living organisms, either in soluble or in membrane-bound form that recognizes specific carbohydrate structures and thereby they may agglutinate cells by binding to cell-surface glycoproteins and glycoconjugates [1]. Till now, several plant lectins have been isolated from plant sources, and most of them have been arranged into the following categories; the legume lectins, monocot mannose-binding lectins, chitin-binding lectins composed of hevein domains, jacalin-related lectins, cucurbitaceae phloem lectins, ribosomeinactivating proteins, and amaranthine lectins [2]. The major sources of lectins are mature seeds and tubers. Small amount of lectins can be found in other tissues such as roots, barks, and leaves [3] that are preferred with great interest according to their diverse biological actions including, cell agglutination [4], anti-fungal [5], antiviral [6], and antiproliferative activities [7, 8].

Agglutination is the most easily method which basically involves the screening of lectin on erythrocytes. The ability to agglutinate cells distinguishes lectins from other sugar-binding macromolecules such as glycosidases and glycosyltransferases. Agglutination occurs when the bound lectin forms multiple cross bridges between the opposing cells [9].

In this research, Sesbania bispinosa and Senna occidentalis plant sources were used for lectins identification. Sesbania bispinosa local name is Dhaincha, Family: Fabaceae, 1-3 m tall, plant decoction as antacid and febrifuge. Bark and seed astringent for diarrhea; seed powder given to induce hunger. Leaf paste applied to small babies all over the body and also given bath against whooping cough. Flowers smoke as mosquito and insect repellent. And another plant Senna occidentalis local name is Kalkasunda. The plant (with the yellow flowers) grows wild on road side. Its fruit is pod brown with yellow margin and seed 20-25 in numbers with greenish brown. Decoction of the whole plant as flatulence and seeds are used in leprosy, erysipelas, pruritus, wounds, ulcers, cough, bronchitis, 
hiccough, asthma, pharyngodynia, fever, and hydrophobia [10]. In this study, we have focused on confirming the lectins in the plant sources by hemagglutination assay.

\section{Experimental}

\section{Collection of seeds}

Initially, Sesbania bispinosa and Senna occidentalis seeds were collected from the local area and pulverized in a mortar and pastel to produce fine powder materials. The powder materials were screened by 50 mesh screen, and fat free powder of seeds were prepared with diethyl ether.

\section{Extraction of lectin}

At first, $25 \mathrm{mM}$ of sodium phosphate buffer with the $\mathrm{pH}$ of 7.4 was added to the fat free powder of the tested sample A and B (50 mL for $10 \mathrm{gm}$ ) and was kept overnight at $4{ }^{\circ} \mathrm{C}$ with occasional stirring. The homogenate were filtered through double layer of silk cloth and centrifuged at 10,000 g for 10 min. The clear supernatants were used as crude extracts.

\section{Protein precipitation by ammonium sulphate}

The supernatants were adjusted to $90 \%$ saturation by adding solid ammonium sulphate and kept for $6-8 \mathrm{~h}$ at $4{ }^{\circ} \mathrm{C}$. The precipitate was collected by centrifugation at 10,000 rpm for $10 \mathrm{~min}$, then dissolved in $20 \mathrm{mM}$ of Tris- $\mathrm{HCl}$ buffer containing $0.5 \mathrm{M} \mathrm{NaCl}, 1 \mathrm{mM} \mathrm{CaCl}, 1 \mathrm{mM} \mathrm{MnCl} 2$ and $1 \mathrm{mM}$ $\mathrm{MgCl}_{2}$ with the $\mathrm{pH}$ of 8. After centrifugation, the clear supernatants were dialyzed against same buffer solution and used as tested samples. The supernatants from Sesbania bispinosa and Senna occidentalis seeds were denoted as tested sample A and B, respectively.

\section{Determination of the protein content by biuret method}

Standard: Standard contains protein $80 \mathrm{gm} / \mathrm{L}$

$20 \mu \mathrm{L}$ of crude extracts, tested samples (A and B), and standard protein sample were added to 1 $\mathrm{mL}$ of total protein reagent in different test tubes, the mixtures were shaken for few times, allowed to react for $10 \mathrm{~min}$ at room temperature. The absorbance of crude, tested samples and standard against the reagent blank were measured within $30 \mathrm{~min}$ at $546 \mathrm{~nm}$ using a UV-visible Spectrophotometer. The amount of protein contents were determined using the biuret method and the following equation.

$$
\mathrm{C}=80 \times \frac{\Delta \mathrm{A}_{\text {sample }}}{\Delta \mathrm{A}_{\text {standard }}}[\mathrm{mg} / \mathrm{mL}]
$$


Hemagglutination assay

Preparation of $2 \% \mathrm{NaCl}$ solution

$2 \mathrm{gm}$ of $\mathrm{NaCl}$ was dissolved in $80 \mathrm{~mL}$ of deionized distilled water in a $100 \mathrm{~mL}$ volumetric flask. The final volume was made up to the mark by adding deionized distilled water.

\section{Preparation of hemagglutination buffer}

$20 \mathrm{mM}$ of Tris- $\mathrm{HCl}$ buffer with the $\mathrm{pH}$ of 7.8 containing $0.15 \mathrm{M}$ of $\mathrm{NaCl}$ and $10 \mathrm{mM}$ of $\mathrm{CaCl}_{2}$ was prepared by dissolving 0.24 gm of Tris-base in about $90 \mathrm{~mL}$ of deionized distilled water. After adjusting the $\mathrm{pH}$ to 7.8 with concentrated $\mathrm{HCl}$, the final volume was made up to $100 \mathrm{~mL}$ with deionized distilled water. Finally, $0.88 \mathrm{gm} \mathrm{NaCl}$ and $0.11 \mathrm{gm} \mathrm{CaCl}_{2}$ were added and dissolved in that buffer.

Table 1. Total protein contain of tested sample.

\begin{tabular}{|c|c|c|c|c|c|c|}
\hline \multicolumn{2}{|c|}{ Steps } & Sources & Volume (mL) & $\begin{array}{c}\text { Absorbance at } \\
546 \mathrm{~nm}\end{array}$ & $\begin{array}{l}\text { Protein content } \\
\text { (mg/mL) }\end{array}$ & $\begin{array}{c}\text { Total protein } \\
\text { (mg) }\end{array}$ \\
\hline \multicolumn{2}{|c|}{ Standard } & - & & 0.41 & 80 & \\
\hline \multirow{2}{*}{$\begin{array}{c}\text { Tested } \\
\text { samples }\end{array}$} & A & $\begin{array}{l}\text { Sesbania } \\
\text { bispinosa }\end{array}$ & 28 & 0.063 & 12.6 & 352.8 \\
\hline & B & $\begin{array}{c}\text { Senna } \\
\text { occidentalis }\end{array}$ & 45 & 0.049 & 9.8 & 441 \\
\hline
\end{tabular}

Table 2. A summary of hemagglutination assay during screening

\begin{tabular}{cccccc} 
Plant & Steps & $\begin{array}{c}\text { Volume } \\
(\mathrm{mL})\end{array}$ & $\begin{array}{c}\text { Lectin activity } \\
(\text { titer } / \mathrm{mL})\end{array}$ & $\begin{array}{c}\text { Total activity } \\
\text { (titer) }\end{array}$ & \% Yield \\
\hline $\begin{array}{c}\text { Sesbania } \\
\text { bispinosa }\end{array}$ & Crude extract & 6 & 512 & 3072 & \\
Tested sample A & 28 & 32 & 896 & $29.21 \%$ \\
occidentalis & Crude extract & 5 & 512 & 2560 & $28.12 \%$ \\
& Tested sample B & 45 & 16 & 720 & \\
\hline
\end{tabular}

\section{Blood collection and preparation}

Blood of human (Group A, B, O and AB), chicken, bovine and goat were used to test the blood group specificity. Samples of human blood were collected from four donors and other bloods were collected 
from the respective species at their slaughter house. All the blood samples were collected in saline and centrifuged for $10 \mathrm{~min}$. The erythrocyte pellet (Red blood cell, RBC) was washed thrice and resuspended in the same saline to prepare a $2 \%$ suspension for hemagglutination assay.

\section{Hemagglutination activity test}

The hemagglutination assay was performed in 96 well microtiter $U$-bottomed plates in a final volume of $100 \mu \mathrm{L}$ containing $50 \mu \mathrm{L}$ serially diluted tested sample with equal amount of hemagglutination buffer (20 mM Tris- $\mathrm{HCl}$ buffer, $\mathrm{pH}$ of 7.8 containing $150 \mathrm{mM} \mathrm{NaCl}$ and $10 \mathrm{mM} \mathrm{CaCl}_{2}$ ) and $50 \mu \mathrm{L}$ of $2 \%$ suspension of erythrocytes previously washed with $150 \mathrm{mM} \mathrm{NaCl}$. After a gentle shaking, the plate was kept at room temperature for $30 \mathrm{~min}$. The visual agglutination titer of the maximum dilution giving the positive agglutination was recorded.

\section{Results and Discussion}

\section{Determination of the protein content by biuret method}

It was found that $10 \mathrm{gm}$ of Sesbania bispinosa and Senna occidentalis seed contained $352.8 \mathrm{mg}$ and $441 \mathrm{mg}$ of total protein, respectively, as presented in Table 1.

\section{Hemagglutination assay}

Hemagglutination assay was performed using mice, chicken, bovine, goat, and human erythrocytes. Screened lectin from the tested sample A was powerfully agglutinated with human (A, $\mathrm{B}, \mathrm{O}$ and $\mathrm{AB}$ ) blood erythrocytes and there was no agglutinating activities in mice, chicken, bovine and goat erythrocytes. So, the sample A showed no human blood group specificity as it agglutinated A, B, $\mathrm{O}$ and $\mathrm{AB}$ all the blood groups tested. This behaviour was observed in other lectins, as well. For example, EspecL (Erythrina speciosa lectin) and BBL (Belamyia bengalensis lectin) can agglutinate all the human blood groups [11, 12]. A different result was also observed for HTTL (Helianthus tuberosus lectin), which could not agglutinate any human blood group (Table 2) [13].

On the other hand, sample B was powerfully agglutinated with chicken erythrocytes and there were no agglutinating activities in mice, bovine, goat and human blood erythrocytes. Minimum agglutination activity were found to be $0.393 \mathrm{mg} / \mathrm{mL}$ in human $(\mathrm{A}, \mathrm{B}, \mathrm{O}$ and $\mathrm{AB})$ blood erythrocytes and $0.613 \mathrm{mg} / \mathrm{mL}$ in chicken erythrocytes for tested sample $\mathrm{A}$ and $\mathrm{B}$, respectively. The results of the hemagglutination activity are presented in Table 3, and the photograph of the hemagglutination activity is shown in Figure 1. The minimum concentration of other lectins from D. batatas [14] was found to be 2.7 and $3.9 \mu \mathrm{g} / \mathrm{mL}$, respectively; whereas AJL (Arisaema jacquemontii lectin) from $A$. jacquemontii [15] required $11.5 \mu \mathrm{g} / \mathrm{mL}$. 
Table 3. Hemagglutination activity of various erythrocytes by tested sample A and B.

\begin{tabular}{cccc} 
Erythrocytes & Group & $\begin{array}{c}\text { Minimum plant concentration required for a visible agglutination } \\
(\mu \mathrm{g} / \mathrm{mL})\end{array}$ & Tested sample B \\
\hline Crude extract & - & Tested sample A & 38 \\
Human & AB & 393 & NIL \\
& A & 393 & NIL \\
& B & 393 & NIL \\
Chicken & O & 393 & NIL \\
Mice & & NIL & 613 \\
Bovine & & NIL & NIL \\
Goat & NIL & NIL \\
& & NIL & NIL \\
\hline
\end{tabular}

NIL, No hemagglutination activity

Figure 1. Hemagglutination activity test of screened lectin

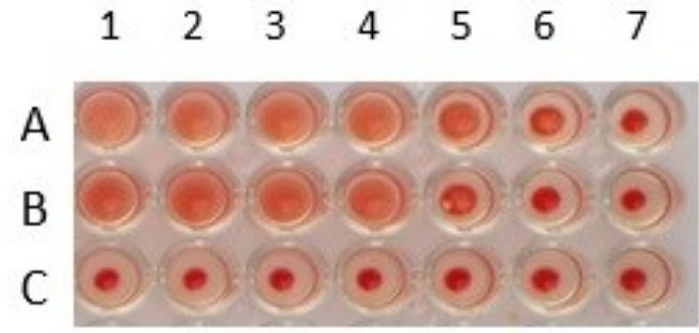

$\mathrm{A}=$ Sesbania bispinos $\mathrm{a}=5$ fold $\quad \mathrm{A}=$ Tested sample A in Tris- $\mathrm{HCl}$ buffer and human erythrocytes

$\mathrm{B}=$ Senna occidentalis $=4$ fold $\quad \mathrm{B}=$ Ttested sample $\mathrm{B}$ in Tris- $\mathrm{HCl}$ buffer and chicken erythrocytes

$\mathrm{C}=$ Control $\quad \mathrm{C}=$ Tris $-\mathrm{HCl}$ buffer and erythrocytes(Control)

\section{Conclusion}

This study was performed to detect and characterize the possible presence of lectins from Bangladeshi plant sources by hemagglutination method. The results revealed that, the Sesbania bispinosa and Senna occidentalis plant sources contain considerable amount of lectin.

\section{Acknowledgements}

This research work has been partially funded by the Faculty of Engineering, University of Rajshahi and University Grants Commission of Bangladesh (sanction order no:A-438/5/52/UGC/Engg.1/2017-2018). 


\section{Disclosure statement}

No potential conflict of interest was reported by the authors.

\section{References}

[1]. Lis H., Sharon N. Chem. Rev., 1998, 98:637

[2]. Van Damme E.J.M., Peumans W.J., Barre A., Rougé P. Crit. Rev. Plant Sci., 1998, 17:575

[3]. Etzler M.E. Academic Press Inc Orlando., 1986, 371

[4]. Konkumnerd W., Karnchanatat A., Sangvanich P. J. Sci. Food Agric., 2010, 90:1920

[5]. Sitohy M., Doheim M., Badr H. Food Chem., 2007, 104:971

[6]. Tian Q., Wang W., Miao C., Peng H., Liu B., Leng F., Dai L., Chen F., Bao J. Plant Sci., 2008, 175:877

[7]. Liu B., Bian H.K., Bao J.K. Cancer Lett., 2010, 287:1

[8]. Kaur A., Singh J., Kamboj S.S., Sexana A.K., Pandita R.M., Shamnugavel M. Phytochemistry., 2005, 66:1933

[9]. Goldstein I.J., Hughes R.C., Monsigny M., Osawa T., Sharon N. Nature, 1980, 285:66

[10]. Warrier P.K., Nambiar V.P.K., Ramankutty C. Orient Longman publication, Madras, 1994, 2:251

[11]. Konozy E.H.E., Bernardes E.S., Rosa C., Faca V., Greene L.J., Ward R.J. Archiv. Biochem. Biophys., 2003, 410:222

[12]. Banerjee S., Chaki S., Bhowal J., Chatterjee B.P. Archiv. Biochem. Biophys., 2004, 421:125

[13]. Suseelan K.N., Mitra R., Pandey R., Sainis K.B., Krishna T.G. Archiv. Biochem. Biophys., 2002, 407:241

[14]. Gaidamashvili M., Ohizumi Y., Iijima S., Takayama T., Ogawa T., Muramoto K. J. Biol. Chem., 2004, 279:26028

[15]. Kaur M., Singh K., Rup P.J., Kamboj S.S., Saxena A.K., Sharma M., Bhagat M., Sood S.K., Sing J. J. Biochem. Mol. Biol., 2006, 39:432

How to cite this manuscript: Mst. Jesmin Sultana*, Fazle Rabbi Shakil Ahmed. Identification of lectins from the seeds of Bangladeshi plants Sesbania bispinosa and Senna occidentalis by hemagglutination assay. Asian Journal of Green Chemistry, 3(4) 2019, 518-524. DOI: 10.33945/SAMI/AJGC/2019.4.8 